\title{
An Anatomy of a Cartel: \\ The National Industrial Recovery Act of 1933 and the Compliance Crisis of 1934
}

\author{
Jason E. Taylor* \\ Department of Economics \\ Central Michigan University \\ Mount Pleasant, MI 48859 \\ taylo2je@cmich.edu \\ Peter G. Klein \\ Contracting and Organizations Research Institute \\ University of Missouri \\ Columbia, MO 65211 \\ pklein@missouri.edu
}

Forthcoming in Research in Economic History 26 (2008)

* Corresponding author. We thank Chris Bailey, Fred Bateman, Juan Carlos Bisso, Harvey James, and George Selgin for helpful comments and Per Bylund and Mark Reffit for valuable research assistance.The usual caveat applies. 


\title{
An Anatomy of a Cartel: The National Industrial Recovery Act of 1933 and the Compliance Crisis of 1934
}

\begin{abstract}
This paper explores the nature and causes of the cartel compliance crisis that befell the National Industrial Recovery Act (NIRA) one year after its passage in 1933. We employ a simple game-theoretic model of the NIRA's cartel enforcement mechanism to show that the compliance crisis can largely be explained by changes in expectations, rather than a change in enforcement policy. Specifically, firms initially overestimated the probability that defection would be met with sanction by the cartel's enabling body, the National Recovery Administration-including a consumer boycott resulting from loss of the patriotic Blue Eagle emblem - and complied with the industry cartel rules. As these expectations were correctly adjusted downward, cartel compliance was lost. We support this hypothesis empirically with industry-level panel data showing how output and wage rates varied according to consumer confidence in the Blue Eagle. The analysis provides insight about cartel performance more generally.
\end{abstract}

JEL: N42, N62, N82, Ll3, L41, L52

\section{Introduction}

Modern cartel theory is typically seen as one of the great successes of game-theoretic economics. However, despite the appeal of the simple models that fill intermediate theory textbooks, many aspects of real-world cartels remain mysterious. Genovese and Mullin's (2001) examination of the early twentieth century US sugar cartel, based on the recorded minutes of member meetings, found that cartel members rarely behaved as standard repeated-game models predict - defections were forgiven, punishments were inconsistent, rules were frequently adjusted, and so on. Moreover, contemporary cartel analysis mostly relies on exogenous shocks to explain cartel formation and breakdown. Comparative-static models identify conditions under which cartel behavior is or is not consistent with optimizing behavior by member firms, relying on changes in these conditions to explain changes in cartel characteristics. For example, the breakdown of previously stable cartels is attributed to such factors as reduced demand growth, increased demand uncertainty, the appearance of new entrants, and exogenous technological change (Eckbo, 1976; Rotemberg and Saloner, 1986; Griffin, 1989; Marquez, 1994; Dick, 1996; Levenstein and Suslow, 2004, 2006; Suslow, 
2005). Fewer studies examine the internal dynamics of cartel behavior exclusive of changes in demand, technology, and other external factors.

Following Genovese and Mullin, among others who have employed historical episodes to gain insight into the contemporary theory of cartel success and failure, we study a hitherto neglected aspect of the cartels created by the US National Industrial Recovery Act (NIRA). Under this legislation, which lasted from June 1933 to May 1935, hundreds of industries in the manufacturing sector drew up specific cartel codes - all of which were public record and whose provisions were legally enforceable through government fines and imprisonment. Many politicians and journalists, and even a few economists, argued that enforced cartelization would boost prices and wages, stimulating recovery from the Great Depression. Empirical evidence suggests that the cartels were initially successful in facilitating collusive outcomes (Hawley, 1966; Weinstein, 1980). ${ }^{1}$ However, several recent studies of the NIRA have noted that the cartel agreements systematically broke down less than a year after they were put into place. Irons (1982), Brand (1989), Alexander (1994, 1997), Krepps (1997), and Taylor (2002), in addition to contemporary accounts of the legislation, describe a widespread "compliance crisis" that rendered the legislation ineffective long before it was struck down by the US Supreme Court in 1935. Understanding the nature and causes of this breakdown provides valuable insight into the internal dynamics of cartel enforcement.

We develop a model highlighting the changes in cartel effectiveness before and after the compliance crisis of Spring 1934. Our analysis emphasizes the particular importance of changing expectations in cartel enforcement and punishment - including consumer and firm perceptions of the Blue Eagle compliance emblem - as a key contributor to cartel breakdown. Because the government was supposed to punish defectors through a combination of fines and removal of the Blue Eagle (which was to have brought a consumer boycott), there

\footnotetext{
${ }^{1}$ Bittlingmayer (1995) argues, by contrast, that cartelization led to cost reductions that mitigated the price increases and output restrictions traditionally associated with cartels. More generally, cartelization may provide efficiency gains by reducing uncertainty about rivals' actions, pooling promotion and distribution costs, establishing standards, and so on (High, 1984-85). Kinghorn (1996) and Troesken (1989) examine late twentieth-century German cartels in this context, while Sjostrom (1989) and Pirrong (1992) similiarly note such cartel efficiencies in ocean shipping.
} 
was no need for the firms themselves to punish defection. However, as it became apparent to firms that government punishment was unlikely, the few initial unpunished defections begat further defections, which soon became a title wave of defections so large that even a few scattered incidences of belated government enforcement could not stop. The broader implications of the study are relevant not just to formal, state-enforced cartels, but also to regulatory and other policies that facilitate collusion (e.g., Rothbard, 1984).

\section{The Logic of the NIRA}

The NIRA was passed by Congress June 16, 1933. Supporters claimed that inter-firm coordination would promote industrial recovery by ending the "ruinous" or "cut-throat" competition widely seen as the cause of the Depression. Industry cooperation was viewed as having been largely successful during World War I and was subsequently portrayed as the best hope for recovery. Donald Richberg, General Council of the National Recovery Administration (NRA), the NIRA's enabling body, explained that "individual self-protection must give way to an orderly common effort" and "that thousands of businessmen themselves should know better than any small group of lawmakers" what specific collective efforts would best stimulate economic recovery (Irons, 1982, p. 97). Following this logic, manufacturing industries were required under the Act to write codes of fair competition, subject to some governmental oversight, specifying detailed rules and regulations for firm behavior.

The NIRA established 765 industry and supplemental codes, each containing several trade-practice provisions. The most common provision - contained in over 400 codes, including those for the pig iron, steel, coal, newsprint, lead, and woodworking machinery industries - was open price filing, which required firms to file their prices with code authorities and give advance notice of any price changes. As is well known in the modern oligopoly literature, open price filing discourages competition by revealing firms' pricing policies to rivals, allowing them to match the price or otherwise "retaliate" against a price-cutting firm. ${ }^{2}$

\footnotetext{
${ }^{2}$ See Krepps (1997) for a discussion of the importance of open price filing provisions under the NIRA
} 
Most industrial codes contained much more specific provisions controlling prices, quantities, capacity, advertising, hiring, and other policies. A 1937 study found approximately 130 categories of trade-practice provisions contained within the NIRA codes. ${ }^{3}$ To illustrate, the Fishing Tackle code ordered that "no manufacturers shall sell or offer for sale any product at a price less than its 'reasonable cost of production and distribution'" (article II, section 1). The Boot and Shoe Manufacturing code mandated that price increases accompany any cost-raising actions such as the use of special shoe boxes or labels (article VIII, section 4). The Hosiery code required firms to submit weekly shipping reports and monthly reports on "production, production and selling costs, shipments, stocks on hand, change[s] in equipment, [and] wages and hours of labor" (article VIII). The Iron and Steel code restricted the production of new capacity: "none of the members of this code shall initiate the construction of any new blast furnace or open hearth or Bessemer steel capacity" (article V, section 2). The Handkerchief code monitored quality: "No member of the industry shall use the words 'Hand Rolled Hem' to designate that class of handmade hem known as 'Whipped Edge,' which latter term means any hem or edge on which the thread used to fasten same is whipped or looped around and encloses the entire rolled edge" (article VII, section 14). The Ice code forbade the "enticement of competitor's employees" in an attempt to limit labormarket competition (article IX, section 2, part i). Although the President was directed to reject codes that "promoted monopolies," the basic provisions of many codes did just this. As Brand (1988, p. 117) puts it, "attempts to mitigate competition also opened the door for businessmen seeking to dispense with competition altogether." 4

While the scope of the regulatory aspects of the specific industry codes was largely up to the cartel participants, all codes had to include wage-rate increases. Although this

codes.

${ }^{3}$ U.S. Committee of Industrial Analysis, 1937, p. 74.

${ }^{4}$ This was particularly true of the early codes. Brand (1988, pp. 106 and 119) notes that with over 700 code applications coming into the government offices within the first six weeks, NIRA administrators could not review every provision of every code, and therefore the early codes most closely reflect those of an unrestricted cartel. 
would presumably only exacerbate the unemployment problem, there was a widespread belief among policy makers, businessmen, and economists that higher wages would increase purchasing power, demand, production, and ultimately, employment (O'Brien, 1989; Vedder and Gallaway, 1993; Taylor and Selgin, 1999). The high-wage doctrine claimed that an increase in wage rates would give workers more money to spend, which would in turn increase the demand for goods and services. This expanded demand would allow firms to increase production and, in the end, hire more workers. ${ }^{5}$ A 1937 study explains the background of the NIRA's wage provisions this way:

[There was a] growing emphasis on the idea that business, in its own interest, needed to pay liberal wages in order to provide the widely distributed purchasing power which was regarded as necessary if the output of mass production was to find an adequate market . . . [The high-wage doctrine] found influential adherents among prominent businessmen, and apparently had appreciable effect on [firms'] actual wage policies (House Document No. 158, 75th Congress, 1st Session, p. 2).

To more quickly put the NIRA's labor provisions into effect, in July 1933 the President's Reemployment Act created a temporary "blanket code" which set wage and hour guideposts that firms were asked to follow until they could pass their own industry codes. Individual firms would sign a pledge to President Roosevelt stating that they would pay workers at least $\$ 0.35$ to $\$ 0.40$ per hour - a minimum wage that exceeded the average wage paid to common labor at the time. Industry-specific codes were more flexible, but one Congressional study of 578 codes found that 338 codes, covering 55 percent of all code employees, specified $\$ 0.40$ an hour or more. In contrast, only 14 codes, covering under five percent of coded employees, specified wages of $\$ 0.30$ an hour or less. In all cases, the law required the industries' average wage rates to be increased. Overall, the average wage rose from $\$ 0.35$ an hour when the NIRA was passed in June 1933 to $\$ 0.43$ an hour one year later, an increase of 23 percent. ${ }^{6}$

\footnotetext{
${ }^{5}$ The high-wage doctrine thus differs from modern efficiency-wage theories, which argue that higher wage rates benefit firms by increasing worker productivity. Here the emphasis is strictly on the perceived boost to aggregate demand.

${ }^{6}$ Hourly wage rates paid to 25 manufacturing industries - the best data source on monthly wage rates in the manufacturing sector, the primary sector covered by the NIRA - rose from 45 cents to 58.8 cents, an increase of nearly 31 percent, during the same period (National Industry Conference Board).
} 
The NIRA's codes of fair competition allowed firms to maintain industry cartels far beyond what would have been feasible on the free market, where cartels generally break down in the absence of an effective enforcement mechanisms. As is well known, firms producing similar products can benefit by coordinating to reduce output, increase prices, or achieve other strategic objectives. However, although decisions to coordinate in this fashion may be collectively beneficial, they may not be individually rational: firms can generally increase their own profit by deviating from any agreement, tacit or explicit. Following Stigler (1964), economists have sought to identify defection and punishment mechanisms that facilitate collusion. While Stigler focused on the ability to detect deviations from the collusive outcome, more recent contributions, following Green and Porter (1984), focus on optimal retaliation, taking the probability of deviation as given. Still, Stigler's basic insight - that cartel members structure their agreements, explicitly or tacitly, to discourage individually rational but collectively harmful behavior - remains one of the best-established results of modern industrial organization.

The NIRA altered the costs and benefits of coordination by specifying how firms would collude and providing legal sanctions for deviations from the cartel codes. In a voluntary cartel, deviations are typically "punished" through retaliation; if one firm cuts its price, the others cut their prices in response, leading to price competition that harms the defector. However, because such a punishment harms the retaliating firms as well, the threat of strong retaliation may not be credible. Indeed, recent studies of early twentieth-century cartels in the bromine (Levenstein, 1997) and sugar (Genovese and Mullin, 2001) industries show that deviations were rarely met with massive retaliation, but rather with small, matching deviations or renegotiation. In a government-enforced cartel, deviation is against the law, so there may be no need for rivals to retaliate. Moreover, under the NIRA the active regulators of the codes were generally the industrial executives themselves, who had proper incentives to monitor participation and could report a rival firm's defection to the local compliance board for punishment. 
The NIRA enforced cartelization in two ways. First, the NIRA codes, once signed by the President, were law. Section 10(b) of the NIRA states that "any such violation of any such rule or regulation shall be punishable by fine of not to exceed $\$ 500$ or imprisonment for not to exceed six months, or both." Each day a violation continued was considered a separate offense and hence subject to a new round of penalties. Compliance boards also required that violators pay wage reparations - usually in the form of back wages to underpaid laborers-before they were considered in compliance. ${ }^{7}$ Assuming firms paid employees the NIRA-suggested $\$ 0.40$ minimum wage, a $\$ 500$ fine, even without reparations, would be the equivalent of 1,250 hours of labor - a severe penalty, particularly for a small firm. Likewise, the cost to a business owner of spending up to six months in jail was certainly not trivial. The overall magnitude of this punishment also depends, of course, upon the expected probability of being caught, the business owner's discount factor, the business owner's subjective aversion to prison, and the expected probability that imprisonment will be imposed for the violation. ${ }^{8}$

The second - and, in the view of the Roosevelt Administration, far more importantenforcement mechanism was the Blue Eagle emblem. Firms deemed to be in full compliance with their industry's code of fair competition were allowed to display the emblem on their storefronts, products, or in their advertisements. ${ }^{9}$ Intermediate, wholesale, and retail goods also had to be purchased from NIRA-compliant firms to avoid losing the Blue Eagle. The text of the NIRA encouraged consumers and producers (and required the federal government) to "support and patronize establishments which have also signed this agreement and are listed as members" of the NRA. The Blue Eagle emblem then supposably allowed con-

\footnotetext{
${ }^{7}$ House Document 158, 75th Congress, 1st Session, p. 48.

${ }^{8}$ In fact, few business owners were imprisoned for cartel violations. However, this is less important than potential violators' expectations of punishment.

${ }^{9}$ Though the ability to display the Blue Eagle was implicit in all codes, some industry codes included more detailed provisions on how the emblem could be displayed. The Men's Clothing Industry code, for example, said that the Blue Eagle insignia had to be attached to all garments. "The privilege of using such labels and the issuance thereof may be withdrawn [from] any such manufacture whose operations, after appropriate hearings . . . shall be found to be in substantial violation" of the cartel code.
} 
sumers to differentiate between firms that had signed codes and remained in compliance with their cartels and firms that either refused to sign or lost the emblem as punishment for a violation.

By encouraging consumers to sign a "Statement of Cooperation" reading "I will cooperate in the reemployment by supporting and patronizing employers and workers who are members of the NRA," Roosevelt essentially called for a nationwide boycott of firms that did not display the Blue Eagle (U.S. National Recovery Administration, 1933c, p. 278). Upon signing this pledge, individuals often were given a "Consumer's Badge of Cooperation," usually in the form of a small lapel pin displaying Blue Eagle that could be worn as a patriotic symbol of support for the President's economic recovery plan. Figure 1 displays these NRA enforcement devices as well as the Blue Eagle emblem. Contemporary anecdotal evidence suggests that many consumers heeded Roosevelt's call, making the Blue Eagle an important part of the NIRA's enforcement mechanism. Despite the Administration's large emphasis on the Blue Eagle as its primary means of enforcement, the emblem has received almost no serious attention in the economics literature on the New Deal.

[Figure 1 about here]

To enforce the cartels, the NRA Compliance Division was established in October 1933. The division had 54 state and branch offices and about 1,400 personnel. Each office had both a director of labor compliance and a director of trade-practice compliance. Enforcement proceeded in stages. After receiving a written complaint, the director of the relevant compliance office would assign a field officer to investigate the alleged violation, and, if appropriate, try to convince the firm to come into compliance. If violation continued, the firm owner would be invited to come into the office to discuss the case with the local compliance director. The state and branch office personnel had little real authority, however; they could simply explain the rules and threaten further action. Only the National Compliance Director in Washington could impose formal sanctions after reviewing the evidence in a closed 
hearing. (The accused was invited to attend the hearing to rebut evidence of the alleged violation, but the identity of the original accuser was supposed to be never revealed.) If the hearing determined that a code violation had occurred, the firm would be invited to sign a certificate promising future compliance. If the firm continued not to comply, the firm owner would receive a telegram from the NRA Administrator's office ordering him to "cease displaying the Blue Eagle and deliver all NRA insignia in his possession to the local postmaster" (U.S. Committee of Industrial Analysis, 1937, p. 70). The NRA Litigation Division was then charged with reviewing the case and referring it to the Department of Justice or the Federal Trade Commission for institution of fines and imprisonment. The NRA itself had no authority to impose penalties beyond stripping the Blue Eagle from violators.

On October 11, 1933 the first use of the NRA Compliance Division's enforcement process made national headlines when Theodore G. Rahutis of Gary, Indiana was sent a telegram from Washington ordering him to give up the Blue Eagle for violating the NRA's wage and hour provisions. The Associated Press quoted a contrite Rahutis saying his restaurant would "take immediate steps to regain our status with the administration." 10

\section{Cartel Behavior under the NIRA: A Strategic Analysis}

The NIRA cartel-code structure and enforcement mechanism can be illustrated with a simple oligopoly model. The NIRA codes attempted to facilitate profit-maximizing collusion on price, quantity, quality, and other forms of competition, but also had to include higher wage rates. Participation was mandatory; firms that violated code provisions risked possible fine, imprisonment, and the loss of the Blue Eagle emblem, leading to a potential consumer boycott.

Consider first the simplest case, a one-period, $n$-firm symmetric Cournot game in which $\pi_{i}^{*}=\frac{1}{n} \pi^{m}$ represents firm $i$ 's payoff from colluding ( $\pi^{m}$ is the industry's monopoly profit), $\pi_{i}^{c}$ is firm $i$ 's profit under Cournot competition, $\pi_{i}^{d}$ is firm $i$ 's profit from defecting while the

\footnotetext{
${ }^{10}$ The Lansing State Journal, October 11, 1933, 1.
} 
remaining $n-1$ firms cooperate, and $\pi_{i}^{z}$ is firm $i$ 's profit from cooperating while another firm defects. Under the standard assumptions that $\pi_{i}^{d}>\pi_{i}^{*}$ and $\pi_{i}^{c}>\pi_{i}^{z}$, the only Nash equilibrium is the one in which each firm defects.

The NIRA changes the payoff structure as follows. Let $\gamma$ be the cost of complying with the NIRA codes - primarily the cost of paying higher wage rates, but also any other compliance costs, including reporting requirements, the costs of using a less-than-optimal technology, and the additional cost of buying from NIRA-compliant supplier cartels. ${ }^{11}$ Let $F$ be the value of the government fine and prison sentence from defecting from the cartel, and $B E$ be the perceived cost of lost business from not being able to display the Blue Eagle. Defectors risk being caught and punished by having their Blue Eagle taken away and being fined or imprisoned. Assume that defectors (instantaneously) lose $B E$ with expected probability $\theta_{1}$ and $F$ with expected probability $\theta_{2}$ but avoid having to pay $\gamma \cdot{ }^{12}$ Cooperation is a Nash equilibrium as long as

$$
\pi_{i}^{*}-\gamma \geq \pi_{i}^{d}-\theta_{1} B E-\theta_{2} F
$$

This expression can usefully be rewritten as

$$
\theta_{1} B E+\theta_{2} F \geq\left(\pi_{i}^{d}-\pi_{i}^{*}\right)+\gamma
$$

where the left-hand side of the inequality represents the expected loss from defecting and the right-hand side represents the expected gain. This formulation emphasizes the importance not only of enforcement $\left(\theta_{1}\right.$ and $\left.\theta_{2}\right)$, but also of the substitutability among the sources of loss from punishment (rivals' reactions $\left[\pi_{i}^{d}-\pi_{i}^{*}\right]$, the government's fine $[F]$, and consumer pressure $[B E])$. For instance, if social pressure to conform to the codes of fair competition is high - giving the Blue Eagle compliance mechanism "bite" - the fine from defecting need not be substantial. Ceteris paribus, a compliance crisis could thus be caused by a change

\footnotetext{
${ }^{11}$ As noted above, the NIRA codes sometimes allowed, or even mandated, firms to adjust prices in response to changes in cost; however, unless consumer demand is perfectly inelastic, the firms will be unable to pass the entire cost increase on to consumers.

${ }^{12}$ For simplicity we assume that the defecting firm can purchase inputs at market prices from non-compliant suppliers. Otherwise the defector still bears some franction of $\gamma$.
} 
in firms' beliefs about of the cost of losing the Blue Eagle, even without a reduction in the fine for violating the NIRA provisions and the likelihood of being caught.

Expressing $\pi_{i}^{*}$ and $\pi_{i}^{d}$ in terms of cost parameters, demand parameters, and $n$ shows how changes in market conditions, firm heterogeneity, and other factors affect the ability of firms to cartelize under the NIRA, holding other factors, such as fines and a potential boycott, constant. Appendix A presents a simple case with linear demand and constant marginal cost. As seen in the Appendix, the right-hand side of inequality (2) - the gain to firm $i$ from violating its cartel agreement, ceteris paribus - is increasing in $n$, decreasing in industry demand, and (generally) decreasing in industry cost. In other words, as in the original Stigler (1964) model, the marginal gain from defecting rather than cooperating increases with the number of firms in an industry, suggesting that NIRA-sponsored collusion should have been easier to sustain in highly concentrated industries. This squares with Alexander's (1994) estimates of "critical concentration ratios" at which industries were able to sustain collusion before and after the NIRA. It also suggests that collusion becomes harder to sustain as industry demand falls. Moreover, as shown for the general case by Schmalensee (1987), and Rothschild (1999), and others, cost asymmetries make collusion harder to sustain; unless output quotas (continuing with the Cournot example) are set relative to costs, highcost firms have a greater incentive to deviate. ${ }^{13}$ The cross-sectional implication is that the ability to sustain collusion in a cartel with mandatory wage increases is sensitive to variation in member firms' capital-labor ratios. The time-series implication is that compliance will tend to break down if capital-labor ratios fall, consistent with Alexander's (1997) general conclusion that firm heterogeneity played an important role in the failure of the NIRA.

The NIRA was originally set to expire after two years, suggesting a finitely repeated game. However, many business owners and policy makers expected the NIRA's cartelenabling provisions to be renewed and maintained indefinitely. Given the great deal of uncertainty about the legislation's duration, it may be useful to view competition under the

\footnotetext{
${ }^{13}$ See Collie (2003) for a contrary view, however.
} 
NIRA as an infinitely repeated game. For simplicity consider an $n$-firm infinitely repeated game in which firm $i$ plays a simple trigger strategy (Friedman, 1971): In period $t$, cooperate if all firms $j \neq i$ cooperated in period $t-1$; otherwise, revert to Cournot output in period $t$ and all subsequent periods. Each firm faces a per-period discount rate of $\delta$. Without the NIRA, firm $i$ gets $\pi_{i}^{*} \cdot \frac{1}{(1-\delta)}$ by cooperating and $\pi_{i}^{d}+\pi_{i}^{c} \cdot \frac{\delta}{(1-\delta)}$ by defecting. As a condition for sustaining cooperation as a subgame-perfect Nash equilibrium, $\pi_{i}^{*} \cdot \frac{1}{(1-\delta)}$ must be greater than or equal to $\pi_{i}^{d}+\pi_{i}^{c} \cdot \frac{\delta}{(1-\delta)}$, which reduces to the standard condition that there is not "too much" discounting, i.e.,

$$
\delta \geq \frac{\pi_{i}^{d}-\pi_{i}^{*}}{\pi_{i}^{d}-\pi_{i}^{c}}
$$

With the NIRA, the cooperating firm $i$ gets $\left(\pi_{i}^{*}-\gamma_{i}\right) \cdot \frac{1}{(1-\delta)}$. By defecting, assuming that $B E$ and $F$ are imposed with probabilities $\theta_{1}$ and $\theta_{2}$ respectively in the period immediately following defection, firm $i$ gets $\pi_{i}^{d}+\left(\pi_{i}^{c}-\theta_{1} B E-\theta_{2} F\right) \cdot \frac{\delta}{(1-\delta)} \cdot{ }^{14}$ The condition for sustaining cooperation is now

$$
\left(\pi_{i}^{*}-\gamma_{i}\right) \cdot \frac{1}{(1-\delta)} \geq \pi_{i}^{d}+\left(\pi_{i}^{c}-\theta_{1} B E-\theta_{2} F\right) \cdot \frac{\delta}{(1-\delta)}
$$

which reduces to

$$
\delta_{N I R A} \geq \frac{\left(\pi_{i}^{d}-\pi_{i}^{*}\right)+\gamma}{\left(\pi_{i}^{d}-\pi_{i}^{c}\right)+\theta_{1} B E+\theta_{2} F} .
$$

As in the one-shot case, the effect of the NIRA on the ability to sustain cooperation depends on the relative magnitudes of $\gamma, \theta_{1}, \theta_{2}, B E$, and $F$. The comparative-statics results are the same in both the one-shot and the repeated games: the likelihood of successful cartelization is increasing in $\theta_{1}, \theta_{2}, B E$, and $F$ and decreasing in $\gamma \cdot{ }^{15}$

\footnotetext{
${ }^{14}$ For simplicity, we assume a constant per-period probability of punishment, regardless of the previousperiod outcome. In other words, the probability of being penalized for defection in a given period is the same as the probability that the penalty will be continued in subsequent periods. Alternatively, we could assume that $\mathrm{F}$ and $\mathrm{BE}$ are imposed only in the period immediately following defection, and not afterward (i.e., firms play a grim-trigger strategy while the government and consumers play tit-for-tat), or that $\mathrm{F}$ and $\mathrm{BE}$ are imposed in every period, or that $\mathrm{F}$ and $\mathrm{BE}$ are imposed with probabilities that are a fuction of time. None of these alternative modeling strategies change the basic insights described below.

${ }^{15}$ As in Hinloopen (2003), for the trigger strategy to be effective in sustaining a noncooperative equilibrium discount rate, the government fine, and the detection probabilities must be sufficiently low.
} 
Of course, the grim-trigger strategy, in which punishment continues indefinitely, may not be realistic. As mentioned above, industry studies by Levenstein (1997) and Genovese and Mullin (2001) suggest that firms rarely respond to defections with massive retaliation. Small defections, even if noticed, are often ignored, while more substantial defections are typically matched in kind. Under the NIRA, firms face an additional disincentive to retaliate: the punisher itself risks fine, imprisonment, and loss of its own Blue Eagle. An alternative modeling strategy is to assume that rivals do not respond to defections at all, relying on government sanction to bring the defector back in line. In this case, the defecting firm's payoff is $\pi_{i}^{d}-\theta_{1} B E-\theta_{2} F$. Inequality 5 thus becomes

$$
\delta_{N I R A} \geq \frac{\left(\pi_{i}^{d}-\pi_{i}^{*}\right)+\gamma}{\theta_{1} B E+\theta_{2} F} .
$$

The comparative-statics results are the same as above: the likelihood of successful cartelization is increasing in $\theta_{1}, \theta_{2}, B E$, and $F$ and decreasing in $\gamma \cdot{ }^{16}$

Of course, interest rates also affect the ability to sustain collusion in a repeated game. As interest rates rise, the short-term gain from defecting increases and the long-term loss from being punished falls, ceteris paribus, making collusion more difficult to sustain. Nominal interest rates remained fairly stable throughout the NIRA period, however, falling slightly from 4.72 percent in July 1933 to 4.36 percent during the April 1934 compliance crisis. ${ }^{17}$ The crisis thus does not appear to have been driven by rising interest rates.

\section{The Good-Patriot Effect}

\footnotetext{
${ }^{16}$ Consistent with Stigler (1964), in the repeated game, as in the one-shot game, collusion becomes harder to sustain as $n$ increases, suggesting that the entry of new firms into the cartelized industries could lead to a reduction in compliance. To see this, assume as before that $\pi_{i}^{*}=\frac{1}{4 n} \frac{(a-c)^{2}}{b}$ and $\pi_{i}^{d}=\frac{1}{16} \frac{(c-a)(n+1)(-a+c-2 g-(a+c+2 g) n)}{n^{2} b}$. The Cournot profit $\pi_{i}^{c}$ can be expressed similarly as $\frac{1}{(n+1)^{2}} \frac{(a-c)^{2}}{b}$. When we substitute these expressions into inequality 5 we get that the right-hand side is increasing in $n$; that is, an increase in the number of firms in an industry raises the critical value of $\delta_{N I R A}$ needed to sustain collusion in the infinitely repeated game, ceteris paribus. (This applies regardless of our assumption about firms' willingness to retaliate.) Even when cartelization is enforced through the twin mechanisms of BE and $F$, defections are more likely when there are many firms in a given industry.

${ }^{17}$ Incidentally, the price level rose around 7 percent during this period, corresponding to a real interest rate of approximately -2.5 percent. Ceteris paribus, such low real interest rates should have made collusion easier to sustain.
} 
As noted above, firms do not always respond to defections with substantial retaliation. Moreover, the NIRA compliance mechanism provided an important disincentive to retaliate - retaliation itself invites legal sanction. Moreover, if consumers take the Blue Eagle seriously, then firms may prefer to respond to a defection by highlighting to consumers their own continued compliance. To see this, imagine that if a defecting firm is caught by the authorities and loses its Blue Eagle, rivals that stick to the cartel code reap windfall profits equal to $G P$-what we call the "good-patriot" effect that a firm receives for cooperating in the face of a defection by a rival firm who now loses the patriotic emblem and invites a consumer boycott. In a symmetric model in which $m$ firms defect, the remaining $n-m$ firms enjoy $G P=\frac{m}{n-m} B E \cdot{ }^{18}$ Under what conditions is $G P$ large enough to prevent firms from retaliating against firms that deviate from the NIRA's provisions?

To simplify the analysis assume that only one firm defects and that the remaining firms act in concert. In other words, each remaining firm compares its payoff under the Cournot equilibrium in which all firms have abandoned the NIRA with the "sucker's payoff" in which the defection goes unpunished. Matching the defection, as we saw above, yields a payoff of $\pi_{i}^{c}-\theta_{1} B E-\theta_{2} F$ (again, assuming that all other firms "punish" by defecting as well). ${ }^{19}$ Allowing the defection to go unpunished yields $\pi_{i}^{z}-\gamma+\theta_{1} G P$, where $G P=\frac{1}{n-1} B E$. Thus, continuing to cooperate while one other firm defects is a best response to that defection if

$$
\pi_{i}^{c}-\theta_{1} B E-\theta_{2} F \leq \pi_{i}^{z}-\gamma+\theta_{1} G P
$$

or, substituting for $G P$ and rearranging terms,

$$
\gamma-\theta_{2} F-\theta_{1} B E\left(\frac{n}{n-1}\right) \leq \pi_{i}^{z}-\pi_{i}^{c}
$$

\footnotetext{
${ }^{18}$ Recall that $\mathrm{BE}_{i}$ is the subjective value of the loss in business that firm i feels it will endure if it loses its Blue Eagle. Since we are assuming firms are symmetric, the firm will estimate that the loss in business to any firm $j$ for defecting will be the same as its own, so $\mathrm{BE}_{j}=\mathrm{BE}_{i}$. Therefore $\mathrm{GP}_{i}$, will consist of the extra business the $n-m$ complying firms will divide equally from the $m B E_{i}$ losses.

${ }^{19}$ Note we are assuming here that industry demand is not fixed; i.e., if all firms in an industry defect, are caught, and lose their Blue Eagles, consumers boycott the industry entirely. Otherwise the Cournot payoff for each firm would simply be $\pi^{c}-\theta_{2} F$, as $B E$ would equal zero. The results below are not sensitive to this assumption.
} 
Cournot profit can be expressed as $\pi_{i}^{c}=\frac{1}{(n+1)^{2}} \frac{(a-c)^{2}}{b}$. To solve for $\pi_{i}^{z}$, assume that cooperating firms continue to produce their NIRA-sanctioned levels of output $\left(x_{i}^{*}\right)$, while the price adjusts to $p^{d}$. Each cooperating firm thus earns a sucker's payoff equal to $\left(p^{d}-c^{\prime}\right) x_{i}^{*}$. That is,

$$
\pi_{i}^{z}=\left(\frac{1}{4} \frac{a-c-2 g+(a+3 c+2 g) n}{n}-c+g\right) \cdot \frac{1}{n}\left(\frac{a-c-g}{2 b}\right),
$$

which reduces to

$$
\pi_{i}^{z}=\frac{1}{8} \frac{(a-c-g)(a-c-2 g+(a-c+6 g) n)}{b n^{2}}
$$

The right-hand side of inequality (8), $\pi_{i}^{z}-\pi_{i}^{c}$, therefore equals

$$
\frac{1}{8} \frac{(a-c-g)(a-c-2 g+(a-c+6 g) n)}{b n^{2}}-\frac{1}{(n+1)^{2}} \frac{(a-c-g)^{2}}{b} .
$$

To simplify this expression, let $a=1, b=1, c=0$, and $g=1$. The expression above reduces to

$$
\frac{1}{4 n}-\frac{1}{8 n+4 n^{2}+4}
$$

and inequality (8), the condition under which firms will continue to cooperate in the face of a defection, becomes

$$
\gamma-\theta_{2} F-\theta_{1} B E\left(\frac{n}{n-1}\right) \leq \frac{1}{4 n}-\frac{1}{8 n+4 n^{2}+4} .
$$

Inspection of inequality (11) reveals that the left-hand side is increasing in $\gamma$, decreasing in $\theta_{1}$ and $\theta_{2}$, decreasing in $B E$, and decreasing in $F$. The left-hand side is increasing in $n$, while the right-hand side is decreasing in $n$. In other words, the inequality is more likely to hold (i.e. the cartel is maintained), ceteris paribus, when $\gamma$ is small, $\theta_{1}$ and $\theta_{2}$ are large, $F$ is large, $B E$ is large, and $n$ is small. These make intuitive sense: The smaller the compliance cost, the more likely a firm will stick with the NIRA agreement. Similarly, a large fine, a high probability of being caught, and a substantial cost from lost business if the Blue Eagle is lost each make continued compliance more likely. Finally, again consistent with Stigler's proposition, collusion is easier to sustain in more concentrated industries, ceteris 
paribus. In short, then, incorporating the good-patriot effect into the analysis reinforces our main results. Indeed, the possibility of good-patriot rewards increases the likelihood that firms will allow defections to go unpunished, maintaining partial cooperation with the NIRA codes instead of a complete breakdown.

\section{The High-Wage Doctrine}

So far we have ignored the high-wage doctrine, the belief that paying higher wages would increase profits by increasing the demand for firms' products. We have modeled the higher wage rates mandated by the NIRA as a cost, specifically as the main component of the compliance cost $\gamma$. What happens to the ability to sustain cooperation under the NIRA if firms regard higher wages, consistent with the high-wage doctrine prevalent at the time, as a benefit to themselves rather than a cost?

If all firms believe in what we might call an "individual high-wage doctrine" - the belief that a firm benefits from paying higher wages to its own workers, regardless of what other firms in the industry are doing - then firms will continue to pay high wages even if they defect from their cartel and cease abiding by the NIRA's other provisions (lowering the perceived cost of $\gamma$, making cartels easier to sustain, without changing the other comparative-statics results). If firms accept the high-wage doctrine but believe the marginal effect of their own wage payments on industry demand is small, then, defectors will free ride on other firms' wage policies by paying lower wages to their own workers, making $\gamma$ the opportunity cost to firm $i$ of paying higher wages instead of free riding. ${ }^{20}$

While the actual (nominal) wage rates mandated by the NIRA were rarely amended throughout the period, an analysis of the high-wage doctrine can help explain a compliance crisis in at least two ways. First, even if no one believed in the high-wage doctrine, a fall in the market wage would constitute an increase in the wage component of $\gamma$, the cost of

\footnotetext{
${ }^{20}$ Taylor and Selgin (1999) show that this desire to force free riders to help boost aggregate demand, rather than the desire to help workers per se, was an important force behind the push for minimum-wage laws during the 1920s and 1930s in the U.S.
} 
paying the NIRA-mandated wage scale, decreasing the likelihood of cooperation. ${ }^{21}$ Second, and perhaps more importantly, firms may have initially believed in the high-wage doctrine, preferring to pay higher wages whether mandated or not, but then lost faith in the merits of high wages. Changes in beliefs about the benefits of paying higher wages thus could help explain the breakdown of the NIRA cartels. Taylor and Selgin (1999) cite contemporary evidence strongly suggesting that some firm owners and policy makers indeed lost faith in the high-wage doctrine as the depression continued throughout the 1930s.

\section{The Compliance Crisis of $\mathbf{1 9 3 4}$}

The analysis above provides a framework for explaining the NIRA's enforcement mechanism and its potential for success or failure in the achievement of cartel outcomes. In particular the model can shed light on the causes of the compliance crisis that took place in the late winter and early spring of 1934, less than a year into the cartel experiment. If we assume that each firm's optimal strategy in absence of any cartel enforcement mechanism is to defect, the model demonstrates that the NIRA's ability to maintain cartelization hinged primarily on firms' expectations of the costs of being caught and punished. These potential punishment costs include fine, imprisonment, and the stripping of the Blue Eagle emblem. Is there evidence that these expectations changed? Consider first the loss of the Blue Eagle.

\section{The Effectiveness of the Blue Eagle Emblem}

The importance of the Blue Eagle depended primarily on consumers' willingness to adhere to Roosevelt's call to boycott firms lacking the compliance indicator. If firms felt that consumers would not take the Blue Eagle into account when deciding where to shop, $B E_{i}$ and $G P_{i}$ are zero, making it more difficult to maintain cartels, ceteris paribus.

As the Blue Eagle compliance badge began appearing on products and in store windows, the Roosevelt Administration continued a daily push of households to "buy under the Blue

\footnotetext{
${ }^{21}$ Of course there is no reliable measure of market wages during the fixed-wage NIRA period. Furthermore, the moderately high inflation rate likely meant that market nominal wages rose, increasing the likelihood of cartel compliance.
} 
Eagle." In an August 7, 1933 speech, NIRA Chief Administrator Hugh Johnson said, "Where should you spend? . . . You should spend under the Blue Eagle. If you spend there you are spending for increased employment. If you spend elsewhere you are hurting the chance" for economic recovery. ${ }^{22}$ Contemporary journalist and Roosevelt critic John T. Flynn (1948, pp. 40-41) reported that "Every instrument of human exhortation opened fire on business to comply [with the NIRA codes] — the press, pulpit, radio, movies. Bands played, men paraded, trucks toured the streets blaring the message through microphones. . . . The President went on the air: 'In war in the gloom of attack,' he crooned, 'soldiers wear a bright badge to be sure that comrades do not fire on comrades. Those who cooperate in this program must know each other at a glance. That bright badge is the Blue Eagle."'

Wolvin's (1968) speech-communications dissertation examined the Blue Eagle campaign as a program of "persuasion and coercion." Interestingly, he notes that the NRA Publicity Division focused much of its attention on women in promoting the Blue Eagle emblem and the boycott of firms lacking it. According to Wolvin, "The bugle call had been sounded to rally the female population of America armed with their pocketbooks" (p. 127). For example, an August 26, 1933, NRA press release stated:

If the women who control the purse strings of the nation use this mighty instrument of mass buying power to support the Blue Eagle, they can assist to bring about a new order in industry. . . . Women should insist on following the sign of the Blue Eagle in all their buying. Every time they spend under the Blue Eagle, they are making jobs for the butcher, the baker, and the candlestick maker and, thereby, helping to achieve security for themselves and to build a better and happier America (quoted in Wolvin, 1968, pp. 132-33).

Moreover, the Administration regularly compared the nation's battle against economic depression to war, noting that during wartime, citizens are asked to make economic sacrifices. The specific sacrifice being asked of consumers was simply to patronize only those firms that bore the patriotic Blue Eagle emblem, even if they charged higher prices. In this vain, Ruth Bryan Owen, U.S. Minister to Denmark, broadcast the following appeal to

\footnotetext{
${ }^{22}$ Lansing State Journal, August 7, 1933, 1.
} 
American women on CBS radio in late August 1933:

In other wars the women's part has been to wait and weep. In this great effort toward recovery women are playing a vital and important part as the industries hoist their banners with the Blue Eagle. . . . If every woman within the sound of my voice should make a resolve, "God helping me, I shall make every effort to assure the success of this program," just that is enough to insure the victory of the greatest of all wars. . . . Mr. President, we will justify the trust you have put in us, gladly and with a high heart we women will do our part (quoted in Wolvin, 1968, pp. 126-27).

Contemporary accounts suggest that consumer respect for the Blue Eagle emblem was substantial and widespread at the onset of the NIRA in the late summer and autumn of 1933. The ubiquitous Blue Eagle, accompanied by the slogan, "We Do Our Part," graced store windows, newspapers, chewing gum wrappers, and was even "reverse-sunburned" on the backs of movie starlets Frances Drake and Toby Wing (Leuchtenburg, 1964, p. 14). Johnson went on a national tour, complete with motorcades and brass bands, promoting the Blue Eagle. In September 1933, a ticker tape parade in New York City drew two million Blue Eagle supporters (Johnson, 1935, p. 267). This prompted the September 12, 1933 edition of U.S. Law Week, a leading legal periodical, to call the Blue Eagle and its consumer's badge of cooperation, "a most effective extra-legal weapon." ${ }^{23}$ On September 4, 1933 Johnson elaborated the Administration's approach to cartel enforcement: "Our first and chief reliance is on public opinion . . . we know that to take away the Blue Eagle is more severe than any puny fine" (quoted in Wolvin, 1968, pp. 194-95). Relating this to our model of firm behavior under the NIRA, the contemporary anecdotal evidence clearly suggests that $B E$ and $G P$ helped to secure compliance during the initial months of the cartel experiment.

The case of the Ford Motor Company, which refused to sign the NRA automobile code, helps illustrate the potential costs of a consumer boycott. Henry Ford was vilified as a traitor in a series of scathing editorials published in many of the nation's leading newspapers. The

\footnotetext{
${ }^{23}$ U.S. Law Week 17, September 12, 1933.
} 
Louisville Courier-Journal, for instance, stated that by not signing onto the NRA Ford was "displaying an astonishing stupidity . . . which may be largely explained by his inordinate egotism" (September 6, 1933). The Milwaukee Journal wrote: "If Henry Ford is too great or too good to wear a Blue Eagle, his is out of tune with his country and out of touch with his fellow Americans" (September 7, 1933). Federal, state, and local government agenciesimportant potential buyers of Ford products - joined consumers in the boycott of Ford. For example, Tennessee state purchasing agent Emmett Hunt announced on August 31, 1933, that his state would not purchase Ford products until the company signed and abided by the NRA automobile code. Governor Pinochot of Pennsylvanian and Governor Brann of Maine announced the next day that their states would also boycott Ford products and many other state and local governments followed suit (Wolvin, 1968, pp. 193-94). This was precisely the kind of publicity and powerful consumer sentiment the NRA had hoped to create. As Johnson noted, "The time is coming when somebody is going to take one of these Blue Eagles off someone's window, and that's going to be a sentence of economic death." 24

While the Blue Eagle campaign appears to have initially succeeded in convincing firms to comply with the cartels or face the consequence of a painful boycott, the wave of patriotic support apparently did not last. Brand (1988, p. 106) notes that by early 1934 consumers had experienced a "decline in moral enthusiasm" for the NRA and its provisions. Hawley (1966, p. 68) likewise notes there was a "reversal in public sentiment" toward the NRA around the same time. After this reversal the Blue Eagle appears to have lost much, if not all, of economic significance. As a contemporary government study noted: "The loss of the right to display the Blue Eagle, to the extent that public interest in patronizing only enterprises which displayed it waned, gradually became a penalty of little consequence" (Committee on Industrial Analysis, 1937, p. 70, emphasis added). Thus firms' perception of reduced consumer enthusiasm for the emblem, represented in our analysis by a reduction in $B E$ (and hence GP), could have played an important role in causing the compliance crisis

\footnotetext{
${ }^{24}$ Lansing State Journal, August 11, 1933, 9.
} 
of early 1934 .

Empirical Evidence on the Role of the Blue Eagle

Systematic empirical evidence on firms' beliefs regarding the value of the Blue Eagle is difficult to obtain. One proxy for a firm's attitude toward the importance of the emblem is its willingness to pay to display it. Firms complying with the NRA cartel codes had the right not only to display the Blue Eagle emblem on their products and in their store windows, but also to include it in their advertisements. Beginning in late July 1933, the Blue Eagle emblem began appearing in print advertisements of NRA-covered firms. To measure its importance, we examined a diverse sample of eight daily newspapers, Atlanta Journal-Constitution, Chicago Tribune, Christian Science Monitor, Lansing State Journal, New Orleans Times-Picayune, New York Times, San Francisco Examiner, and Washington Post. We observe the first 25 advertisements each Thursday between August 3, 1933 and June 6, 1935, just after the NIRA was ruled unconstitutional, and record how many of these displayed the Blue Eagle emblem. Thus each weekly observation records the percentage of 200 advertisements that display the patriotic emblem. Figure 2 shows a five-week central moving average of the percentage of ads carrying the patriotic emblem during the pertinent months. ${ }^{25}$

[Figure 2 about here]

The data suggest that firms' beliefs in consumer enthusiasm for the Blue Eagle emblem were strongest in September and October of 1933 when as many as 44 percent of ads contained the emblem (a significant number considering that the NIRA applied only to manufacturing and retail firms, with a few minor exceptions). A noticeable drop-off began in November and December 1933. Table 1 shows the monthly averages, by newspaper, for

\footnotetext{
${ }^{25}$ The first two and final two observations reported are actual numbers rather than the five-week central moving average.
} 
the last five months of 1933. In all but one case the monthly average declined between October and November, and in all eight cases it declined between November and December.

[Table 1 about here]

During this time the NIRA faced a wave of challenges. For example, on November 27, 1933, eighty-five percent of Chambersburg, Pennsylvania restaurants voluntarily surrendered their Blue Eagles saying that the restaurant code was bringing financial ruin. Then on December 2, 1933, the entire Lincoln, Nebraska compliance board resigned in protest of a lack of enforcement resources from Washington. A few days later, members of the Lowell, Massachusetts compliance board likewise resigned. Such episodes, which made national news, gave the NRA and its Blue Eagle symbol a black eye and likely played an important role in the apparent decline in enthusiasm for the emblem. By January 1934, only around 22 percent of ads, or around half of the number at its earlier peak, displayed the Blue Eagle. Another small wave of the emblem's disappearance began in late May and June of 1934. Interestingly, this is correlated with the release of a report by the National Recovery Review Board, headed by Clarence Darrow, which painted the NRA in an unfavorable light as having supported monopolies at the expense of small businesses. By January 1935, and for the remaining five months in which the Blue Eagle continued to be the official symbol of compliance with the NIRA, only around 5 percent of all ads carried the emblem.

That so many firms went to the initial effort of including the emblem in their advertisementsand in many cases, the major theme of the ad was simply to proclaim the firm's compliance with the NIRA rather than information about the quality or price of their product - in the fall and winter of 1933-34 suggests that firms believed that the Blue Eagle carried weight with consumers. Such a belief, coupled with a fear that defection from the NIRA could result in loss of the emblem, would clearly have made compliance with the cartels more likely. Perhaps more telling, the fact that the percentage of advertisements carrying the emblem fell so dramatically in the Winter and Spring of 1934, even though it was still the official 
emblem of compliance, strongly suggests that the Blue Eagle lost much of its behavioral significance and hence lost its ability to help firms sustain collusion.

An examination of the Blue Eagle in advertisements of some specific firms across this time period may also be of value. While collecting our weekly observations, we tracked the ads of several specific firms looking for any patterns in behavior. We searched for two patterns explicitly. First, we wanted to confirm that what Figure 2 measures is the adoption and subsequent dropping of the Blue Eagle in advertisements of the same firms rather than a change in the composition of advertising firms in the sample. It was clear from our analysis that indeed it was the case that individual firms in our sample displayed and then dropped the emblem. For example, Moore's Retail consistently displayed the Blue Eagle in its San Francisco Examiner advertisements until February 8, 1934, and then dropped it in all subsequent advertisements. Likewise Fanny Farmer Candies regularly displayed the emblem in its advertisements in the Christian Science Monitor until March 29, 1934 after which time it stopped. There were some exceptions as Holmes Retail regularly included the Blue Eagle in its advertisements in the New Orleans Times Picayune all the way until June of 1935, when we stopped collecting data since the legislation had been ruled unconstitutional.

The second pattern we explicitly looked for was whether the dropping of the emblem from advertisements generally corresponded to the firm employing a new advertisement or whether the emblem was removed from an existing advertisement. It seems a far stronger statement of a firm's lack of enthusiasm for the emblem for it to actually remove the Blue Eagle from an existing ad than it is to simply decide not to include it in a new one. While we looked for this pattern anecdotally in all the papers, we were a bit more systematic with respect to this question for the Christian Science Monitor. We tracked seven companies that both had relatively stable advertisements in the Monitor and displayed and dropped the Blue Eagle during the sample. Of these seven, five dropped the Blue Eagle from an existing advertisement, while for the other two the dropping of the emblem corresponded 
with a change in advertisement. Generally speaking, from our analysis of advertisements from all eight papers we conclude that the emblem's disappearance was by no means limited to a change in advertisements.

To see if the fading importance of the Blue Eagle contributed to cartel failure, as described in our model, we construct an industry-level panel of monthly data on output and wage rates, the former as a measure of firms' success in obtaining collusive outcomes and the latter as a measure of compliance with the NIRA's wage provisions. For the output regressions, we use the 66 industries in the National Bureau of Economic Research Macrohistory Database that were covered by a specific NIRA code from January 1927 to December 1937. Our wage regressions use the 30 of these industries for which average hourly earnings data are also reported.

For each industry in our sample we obtain from the corresponding NIRA code of fair competition the date in which the industry code was passed. The opening pages of each code generally listed the specific subcategories of firms or production that fell under the jurisdiction of the code, helping us to match each industry to its specific cartel code. Table 2 lists the 66 industries in the sample, marking with an asterisk the subsample of 30 industries for which we also have average hourly wage data, and the date that each industry's code was passed. From this information we create dummy variables for each industry's precode months (from July 1933 to the month the industry code was passed [if a code was passed after the 16th of the month we counted that month as a pre-code month]) and the code months (from the month of code passage to May 1935, when the NIRA was ruled unconstitutional).

[Table 2 about here]

To control for important non-NIRA factors that could have influenced output and hourly earnings, each regression includes the real money supply, real government spending, real 
government revenue, and time trend variables. ${ }^{26}$ We also include fixed effects to control for omitted variables that vary across industries but do not change over time. One important factor that both could have affected industry decisions and varied over time is capacity utilization. For example, an industry operating near 100 percent of its capacity would likely have a very different optimal response to changing economic conditions or institutions (such as cartelization) than one operating at only 20 percent capacity. We create a capacity utilization proxy by dividing monthly production by the industry's maximum level of monthly production between January 1927 and December 1929. In each regression, we include our capacity utilization proxy lagged one period so that its value is exogenous to movements within a particular month.

Table 3 reports the results of GLS panel regressions employing fixed effects and cross-section weights. To control for serial correlation we use log differences (percentage changes) rather than levels. The results of specifications (1) and (3) suggest that output growth fell and real average houlry earnings growth rose during the pre-code months, when firms were free to negotiate over the contents of their industry's cartel code, and during the months in which the code was in effect (the earnings increases are not statistically significant during the industry-code months, however). This suggests that the NIRA was generally successful in its quid pro quo of facilitating cartels in exchange for higher average hourly earnings.

[Table 3 about here]

In specifications (2) and (4) we add our monthly measure of the Blue Eagle's importance as proxied by its appearance in newspaper advertisements. Since our regressions employ monthly data, we use the moving average of the first observation of each month for our analysis. As the table shows, output growth fell more sharply, and real average hourly earnings grew significantly faster, when the Blue Eagle was viewed by firms as being eco-

\footnotetext{
${ }^{26}$ The results are not sensitive to the inclusion of the time trend.
} 
nomically important. Moreover, when one controls for the prominence of the Blue Eagle emblem, output growth rose (rather than fell) and earnings fell (rather than rose) during the NIRA code months. These results offer empirical support to the notion that perceptions of the Blue Eagle emblem played an important role in cartel complaince and breakdown under the NIRA.

As with any empirical study of this period the results should be interpreted with caution as there were several important institutional changes that cannot easily be measured and controlled for. Moreover, the causality could run in the opposite direction - as the NIRA cartels fell apart, the Blue Eagle became less important. (Unfortunately, we lack sufficient time-series observations under the NIRA to reliably conduct Granger causality tests.) However, we also find that the Blue Eagle's importance is negatively correlated with firms' defections from their cartels. Figure 3 reports the number of weekly complaints about trade-practice provisions received in compliance field offices between November 1933 and January 1935. We take this to be a reasonable proxy for number of defections. The correlation coefficient between trade-practice complaints and the percent of advertisements carrying the Blue Eagle is -0.608 and is statistically significant at the 5 percent level. Thus the more important the Blue Eagle emblem, the fewer the defections. This offers further evidence that firms' perceptions of the value of the Blue Eagle emblem helped drive cartel success and failure under the NRA.

[Figure 3 about here]

\section{Government Enforcement through Fine and Imprisonment}

According to a 1937 government study the NRA's methods of "education and conciliation, at first relatively successful in bringing about compliance, gradually became less effective [so that] greater emphasis was placed by [the] NRA upon recourse to actions in the courts." ${ }^{27}$ Figure 3 reveals that complaints of code violations increasingly flooded NRA

\footnotetext{
${ }^{27}$ U.S. Committee of Industrial Analysis, 1937, p. 70.
} 
compliance offices, spiking in April and May of 1934. Johnson had a strong aversion to litigation and had hoped all along that the Blue Eagle emblem, in and of itself, would be sufficient to facilitate code compliance. Furthermore, the NRA's lawyers generally hesitated in pursuing violators too vigorously, fearing the legislation might not hold up in court. As Irons (1982, pp. 34-35) notes, this combination of factors made the Litigation Division slow to pursue cartel violators.

In early 1934, it became obvious that some new action was needed to stop widespread defections. Blackwell Smith, the NRA's chief lawyer, prepared a staff memo outlining what he called a "Machiavellian" strategy of "threats" and "tricks" designed to "bring to swift justice locally well known chiselers." 28 This strategy—perhaps best called "smoke and mirrors" - entailed pursuing a handful of high-profile targets to give the illusion that punishment of violators was widespread. To illustrate this strategy in practice, on February 28, 1934, Cornelia Bryce Pinchot, wife of the Pennsylvania governor Gifford Pinchot, charged that "Blue Eagles are adorning sweat shops in hundreds of towns in Pennsylvania" because of the lack of NRA enforcement against violators. At the same event, Louis Waldman, spokesman for the Socialist Party said, "We support the NRA... but it has failed ... because of the methods Gen. Johnson has used for its enforcement." ${ }^{29}$ The very next day, the NRA responded by publicly calling for the removal of the Blue Eagle emblem from 12 large firms and referred 10 of these cases to the Department of Justice and one to the Federal Trade Commission for pursuit of fines and imprisonment. ${ }^{30}$ While this flurry of NRA activity made national headlines, in hopes of spreading the illusion of widespread enforcement, the reality was that such broad action was the exception and not the rule.

The NRA Compliance and Litigation Divisions also employed what we call a "pick-yourbattles-wisely" strategy. When compliance officers pursued a cartel violator in court, they

\footnotetext{
${ }^{28}$ Blackwell Smith to Averell Harriman, April 9, 1934, memo file, January-April 1934, Box 45, Richberg Papers, LC.

${ }^{29}$ Both quotes are from The Washington Post, March 1, 1934, 1.

${ }^{30}$ The Washington Post, March 2, 1934, 1.
} 
generally attempted to do so in jurisdictions with judges expected to be NIRA supporters. Of the cases that made it to district courts on constitutional grounds, 71 percent of Republican judges ruled against the NRA, while 80 percent of Democratic judges ruled in its favor (Irons, 1982, p. 56). Because court losses could hurt cartel compliance (represented in our model by a drop in $\theta_{2_{i}}$ ), NRA compliance officers had to consider carefully not only the severity of a defection, but also the likelihood that punishment could be secured in court when considering whether or not to take legal action.

By the time the legislation was ruled unconstitutional in May 1935, NRA state and branch offices had processed a total of 155,102 complaints. Of these, 88,872 were deemed valid but handled by "education and [threatened] coercion" in state offices. Only 7,136 cases were referred to the National Compliance Board in Washington and of these, 2,064 cases were referred to the Litigation Division. Only 564 cases reached the courts and many of these were still pending, and hence dropped, after Schechter. ${ }^{31}$

\section{The Nature and Causes of the Compliance Crisis: Implications of the Model}

Incorporating these facts into the game-theoretic model presented above strongly suggests that changing perceptions, rather than changes in enforcement, are most responsible for the compliance crisis. The stated penalties of a $\$ 500$ fine and up to six months in jail for cartel violations remained in place throughout the duration of the NIRA, so our $F$ can be viewed as constant. Furthermore, from the above figures on litigation and code violation complaints, the actual probability of being caught and fined or imprisoned does not seem to have changed significantly over time either. As the case numbers suggest, the NRA Compliance Division rarely acted on complaints beyond politely asking violators to come into compliance. Instead, $\theta_{1}$ and $\theta_{2}$, the expected probabilities of being caught and punished, appear to have fallen from incorrectly high levels to more realistic ones during late 1933 and early 1934 .

\footnotetext{
${ }^{31}$ U.S. Committee on Industrial Analysis, 1937, p. 72.
} 
This raises an important question: which firms defected first? The obvious answer is that the first firms to defect were those with better information about the true values of $\theta_{1}$ and $\theta_{2}$. Suppose, for example, we allow firms to have different beliefs about the likelihood of punishment. Assume that each firm $i$ has beliefs $\theta_{1}^{i}$ and $\theta_{2}^{i}$ drawn randomly from normal distributions of $\theta_{1}$ and $\theta_{2}$ with means $\bar{\theta}_{1}$ and $\bar{\theta}_{2}$ and standard deviations $\sigma_{1}^{i}$ and $\sigma_{2}^{i}$, respectively. In the initial periods of the game, the firms most likely to defect are those whose beliefs $\theta_{1}^{i}$ and $\theta_{2}^{i}$ are at the bottom of the respective distributions. In subsequent periods, firms in continued compliance observe that defectors are punished less frequently than expected, and these firms adjust their beliefs about punishment by adopting lower values of $\theta_{1}^{i}$ and $\theta_{2}^{i}$, leading to additional defections, and so on.

Industry case studies strongly support such a sequence of events. According to David T. Mason, executive officer of the Lumber Code Authority, the "code worked well for many months, during which time undoubtedly the vast majority of the industry did comply [mainly] because they feared the action which would be taken upon failure to comply." However, Mason noted, a few violations sowed "the seeds of trouble. . . . As time went on with lack of action by government enforcement agencies . . . [violators] became more brazen and outspoken, encouraging their neighbors in similar violations" (Mason, 1935, p. 23). Mason noted that by June 1934, a full-fledged crisis left the code virtually ineffective. Although the NRA Litigation Division did belatedly push the Department of Justice to prosecute a few lumber code violators, Mason suggested that this should have been done from the start. "Such action would have been in accordance with the military theory that the first action toward a raw recruit is to teach him discipline and respect for his organization" (p. 24).

Similar events occurred in the macaroni industry. Alexander (1997) notes that head of the macaroni code, G. G. Hoskins, pleaded with government compliance administrators throughout 1934 to prosecute large macaroni firms who were allegedly violating the macaroni code's price provisions. However, according to Alexander (p. 331), the NRA was "divided against itself, with various departments rendering conflicting opinions about 
the legality of the code provisions." Alexander cites a January 1935 memo from Hoskins, in which he noted that the cartel "membership at large has come to believe that all our statements that the Code could be enforced have been false" (p. 332).

The lack of enforcement action from Washington also served to alienate members of local compliance boards, further exacerbating the compliance crisis. The December 1933 episodes mentioned earlier whereby the NRA Compliance Boards of Lincoln, Nebraska and Lowell, Massachusetts resigned in protest illustrate the point. Members of the Lincoln board noted that while the local board had relayed several cases of non-compliance to the National Compliance Board in Washington for removal of the Blue Eagle and further legal action, "there has been nothing done." The local board estimated that only 30 percent of Lincoln firms were in compliance with the codes even though almost all firms displayed the Blue Eagle. ${ }^{32}$ In Lowell, the Board's letter of resignation noted, "We repeatedly have requested cooperation and assistance which has not been afforded us [from Washington] which has been annoying and embarrassing." ${ }^{33}$ Because cases such as these made national news, they clearly had an impact upon both the perceived probabilities that government enforcement would be forthcoming in the face of a violation and consumers' actual response to "buy under the Blue Eagle" as measured in our model by BE and GP.

Essentially, it appears that in the summer and autumn of 1933 our key inequalitiesequation (1) for the one-shot or finitely repeated game and equation (6) for the infinitely repeated game - held, implying that collusion was a Nash equilibrium. Over time, however, some firms' subjective evaluations of $\theta_{1}, \theta_{2}$, and $B E$ changed (recall the actual value of $F$ itself did not change) so that the expected payoff from defection came to exceed the expected payoff from compliance. Interestingly, this does not appear to have happened all at once. Some business owners appear to have continued to view the NIRA enforcement mechanism as having weight so that the inequality in equation (8), which provides the

\footnotetext{
${ }^{32}$ Washington Post, December 2, 1933, 8.

${ }^{33}$ Washington Post, December 12 1933, 1.
} 
condition under which firms will continue to abide by a cartel agreement in the face of a defection, held. Suggesting an important role for $\theta_{2}$ in particular, a 1937 study concluded that "compliance tended to break down in industries, and in areas generally, in which an alleged violator was allowed to continue non-compliance with impunity" (Committee on Industrial Analysis, 1937, p. 72). As defection became more common it became increasing clear that $\theta_{1}, \theta_{2}, B E$, and $G P$ were actually quite small, and cartel maintenance became exceedingly difficult. In short, the NIRA's enforcement mechanisms appear to have worked initially, but began to fail as firms realized that punishment, both from the government and from patriotic consumers, was unlikely. Of course, the fact that firms were still exempt from antitrust law could have allowed some industries - those for which collusion was a Nash equilibrium even in the absence of the NIRA codes - to maintain effective cartels after the compliance crisis.

\section{The Model in Light of Existing NIRA Literature}

Our analysis of the NIRA cartel enforcement mechanism and compliance crisis strongly complements recent empirical studies of the NIRA. Alexander (1994, 1997) and Krepps (1997), both using industry-level data on price-cost margins, find that the effects of the NIRA varied widely across industries. Both authors attribute this largely to differences in enforceability of certain provisions of codes and to structural differences within industries affecting the gains to defection. Krepps, for example, finds that industries with codes that contained the relatively easily enforceable provision of open-price filing fared much better in raising price-cost margins than those that did not. This suggests that the NIRA compliance mechanism itself was not able to enforce most other code provisions.

Alexander (1997), using the percentage change in establishment size between 1929 and 1933 as a proxy for cost heterogeneity, finds that cost heterogeneity is negatively correlated with profit (proxied by percent changes in dollars available for fixed costs between 1933 and 1935 and percentage change in price cost margin for same time). ${ }^{34}$ Consistent with the no-

\footnotetext{
${ }^{34}$ Defection, Alexander notes, was likely more attractive to a low-cost firm in a heterogeneous-cost industry
} 
tion of a crisis in compliance, Alexander notes that, "The NRA never took a decisive stand on enforcement . . . as soon as low-cost firms realized they were able, they reverted back to competition on the basis of low costs" (p. 327). Complementary to our general conclusions, this suggests that the NIRA enforcement mechanism worked initially, but became largely inept after firms no longer feared punishment. While our paper complements the existing literature, it adds a detailed examination of the NIRA cartel enforcement mechanism, particularly the role played by consumer and producer beliefs in the power of the Blue Eagle emblem, as well as an examination of specific enforcement strategies employed by the NRA Compliance and Litigation Divisions. Furthermore, our study provides the most detailed analysis of the nature and causes of one of the defining moments of the NIRA-the compliance crisis of 1934 .

\section{Conclusion}

Grossman (2004, p. 7) notes that "in any discussion of cartel behavior, it is easier to ask the questions than to find clear-cut answers." While the so-called "compliance crisis" has been a key feature of recent empirical analyses of the National Industrial Recovery Act, scholars have done little in the pursuit of answers behind its nature and causes. To gain general insight into the mechanics of cartel success and failure we explore the compliance crisis that befell the government-sponsored cartels of the 1930s, when over 700 industries had their own specific cartel code passed into law. The game-theoretic model developed here demonstrates the importance of expectations of punishment, rather than the objective probabilities, for the success and failure the NIRA cartels. Clearly, as long as firms expected to be punished for violating their cartel codes and expected to lose customers upon being stripped of the Blue Eagle emblem, firms' best responses were generally to comply with the NIRA cartel codes. However, as consumers lost enthusiasm for the Blue Eagle,

than for an average firm in a homogeneous-cost industry. While admitting that her analysis is a "very rough" attempt to test empirically the effects of heterogeneity on cartelization, Alexander notes her analysis is primarily meant to offer some empirical support to her macaroni case study and her model on the effects of cost heterogeneity. 
firms realized that the NIRA compliance mechanism - including the Blue Eagle emblemwas largely innocuous, and firms began to defect from the cartel. When these defections went unpunished, other firms lowered their evaluations of punishment, leading to further defections.

By the time the NRA Litigation Division began referring violators for prosecution in earnest, the compliance crisis was too far underway. The NRA Compliance and Litigation Divisions attempted to compensate with what we have called the "smoke-and-mirrors" and "pick-your-battles-wisely" strategies. Specifically, the NRA attempted to prosecute a few high-profile firms in jurisdictions with NIRA-friendly judges. However, with thousands of complaints flooding field offices each month, these strategies were not enough to make the threat of prosecution credible in the eyes of most cartel participants. The lethal combination of declining enthusiasm for the Blue Eagle emblem and declining expectations of punishment ultimately doomed the NIRA cartel experiment.

Our model and empirical work illustrate the main features of this argument, but they are of course not definitive. The model can be extended in several ways. For example, following Hinloopen (2003), we could model belief formation explicitly, rather than treat beliefs as exogenous shift parameters. ${ }^{35}$ More generally, we can try to model additional ways in which the legal and competitive environments changed during the course of the NIRA. As Levenstein and Suslow (2006) point out in their recent survey of empirical research on cartels, the key to cartel stability over time is flexibility - cartels tend to stay together when firms can adjust cartel agreements in light of changing economic conditions. Our model highlights the most important of these changes during the NIRA period-consumer beliefs about the Blue Eagle emblem and firms' beliefs about government enforcementbut other changes could be important as well. Additional empirical work on the spatial

\footnotetext{
${ }^{35}$ Hinloopen (2003) studies price-fixing cartels and models the probability of detection and government fine as a function of cartel characteristics, the resources available to the enforcement authority, and the number of periods in which the cartel has been in operation. The qualitative results of his analysis are similar to ours.
} 
distribution of cartel defections under the NIRA would be valuable to test the extent of a geographic "contagion effect" in cartel breakdown. We look forward to pursuing these and other extensions in future work. 


\section{Appendix A: Comparative-Static Analysis of One-Period Model}

Consider a one-period, $n$-firm symmetric Cournot model with linear demand given by $p=a-b X$ where $p$ is price, $X$ is total industry output, and $a$ and $b$ are parameters. Firms produce output $x$ at a constant marginal $\operatorname{cost} c$. When complying with the NIRA, the firm's costs increase from $c$ to $c^{\prime}$ (where $\left.\gamma=\left(c^{\prime}-c\right) x\right)$.

Under perfect collusion firm $i$ produces output $x_{i}^{*}=\frac{1}{n}\left(\frac{a-c^{\prime}}{2 b}\right)$, representing one $n$th of the monopoly output. The market price $p^{*}=\frac{1}{2}\left(a+c^{\prime}\right)$ (the monopoly price) and firm $i$ 's profit $\pi_{i}^{*}=\frac{1}{4 n} \frac{\left(a-c^{\prime}\right)^{2}}{b}$.

If firm $i$ deviates by maximizing its own profit, assuming that other firms continue to produce their shares of the collusive output, then firm $i$ chooses $x_{i}$ to maximize $\left(a-b\left(x_{i}+\right.\right.$ $\left.X_{-i}^{*}\right) x_{i}-c x_{i}$, where $X_{-i}^{*}$ represents the (cartel-level) output of all firms $j \neq i$. We assume that the defecting firm avoids the costs of compliance $\gamma$, thus facing per-unit costs of $c$ rather than $c^{\prime}$. The first-order condition is $a-2 b x_{i}-b X_{-i}^{*}-c=0$, which implies that

$x_{i}^{d}=\frac{a-b X_{-i}^{*}-c}{2 b}$. Noting that $X_{-i}^{*}$ can be expressed as $\frac{n-1}{n}\left(\frac{a-c^{\prime}}{2 b}\right)$, letting $g=c^{\prime}-c$, and making the appropriate substitutions, we obtain the following solution:

$$
\begin{gathered}
x_{i}^{d}=\frac{1}{4} \frac{a-c+a n-n c}{n b}, \\
p^{d}=\frac{1}{4} \frac{a-c-2 g+(a+3 c+2 g) n}{n}, \text { and } \\
\pi_{i}^{d}=\frac{1}{16} \frac{(c-a)(n+1)(c-a+2 g-(a+c-2 g) n)}{n^{2} b} .
\end{gathered}
$$

Note that as expected, firm $i$ 's profit from defecting, $\pi_{i}^{d}$, is greater than its profit from cooperating, $\pi_{i}^{*}$.

We can now do some comparative statics on the effectiveness of the NIRA under various market conditions. For instance, the right-hand side of inequality (2) in the main text above can be expressed as

$$
\frac{1}{16} \frac{(c-a)(n+1)(c-a+2 g-(a+c-2 g) n)}{n^{2} b}-\frac{1}{4 n} \frac{(a-c)^{2}}{b}+\gamma,
$$


which is an increasing function of $n .^{36}$ a decreasing function of $a$, and a (generally) decreasing function of $c$. If we model changes in industry demand as vertical, parallel shifts in the demand curve, then changes in demand are captured by changes in $a$, just as changes in the industry's cost structure are captured by changes in $c$.

\footnotetext{
${ }^{36}$ Note that $\gamma=\left(c^{\prime}-c\right) x^{*}$; i.e., the cost of compliance is computed assuming the firm is producing its cartel-specified level of output.
} 


\section{References}

Alexander, Barbara. "Failed Cooperation in Heterogeneous Industries Under National Recovery Administration." Journal of Economic History 57, no. 2 (1997): 322-44.

Alexander, Barbara. "The Impact of the National Industrial Recovery Act on Cartel Formation and Maintenance Costs." Review of Economics and Statistics 76, no. 2 (1994): 245-54.

Alexander, Barbara and Gary D. Libecap. "The Effect of Cost Heterogeneity in the Success and Failure of the New Deal's Agricultural and Industrial Programs." Explorations in Economic History 37 (2000): 370-400.

Athey, Susan, Kyle Bagwell, and Chris Sanchirico. "Collusion and Price Rigidity." Review of Economic Studies 71, no. 2 (2004): 317-49.

Bittlingmayer, George. "Output and Stock Prices When Antitrust is Suspended: The Effects of the NIRA." In The Causes and Consequences of Antitrust: A Public Choice Perspective, edited by Fred S. McChesney and William F. Shughart II. Chicago: University of Chicago Press, 1995.

Brand, Donald. Corporatism and the Rule of Law: A Study of the National Recovery Administration. Ithaca: Cornell University Press, 1988.

Collie, David R. "Sustaining Collusion with Asymmetric Costs." Working paper, Cardiff Business School, Cardiff University, 2003.

Cooper, Russel and John Haltiwanger. "Automobiles and the National Industrial Recovery Act: Evidence on Industry Complementaries." Quarterly Journal of Economics 108, no. 4 (1993): 1043-71.

Dick, Andrew R. "When Are Cartels Stable Contracts?" Journal of Law and Economics 39, No. 1 (1996): 241-83.

Eckbo, Paul L. The Future of World Oil. Cambridge: Ballinger Publishing, 1976.

Flynn, John T. The Roosevelt Myth. New York: Devin-Adair, 1948. Reprint, San Francisco: Fox \& Wilkes, 1998.

Friedman, James W. "A Non-Cooperative Equilibrium for Supergames." Review of Economic Studies 38, no. 1 (1971): 1-12.

Genovese, David, and Wallace P. Mullin. "Rules, Communication, and Collusion: Narrative Evidence from the Sugar Institute Case." American Economic Review 91, no. 3 (2004): 379-98.

Green, Edward J., and Porter, Robert H. "Noncooperative Collusion under Imperfect Price Information." Econometrica 52 (1984): 87-100.

Griffin, James M. "Previous Cartel Experience: Any Lesson for OPEC?" In Lawrence R. Klein and Jaime Marquez, eds., Economics in Theory and Practice: An Eclectic Approach. Dordrecht: Kluwer Academic Publishers, 1989, pp. 179-206. 
Grossman, Peter Z. "Introduction: What do we Mean by Cartel Success?" In Peter Z. Grossman, ed., How Cartels Endure and How They Fail: Studies of Industrial Collusion. Northhampton, Mass: Edward Elgar, 2004, pp. 1-8.

Hawley, Ellis W. The New Deal and the Problem of Monopoly. Princeton: Princeton University Press, 1966.

High, Jack. "Bork's Paradox: Static vs. Dynamic Efficiency in Antitrust Analysis. Contemporary Policy Issues 3, no. 2 (1984-85): 21-34.

Himmelberg, Robert F. The Origins of the National Recovery Administration: Business, Government, and the Trade Association Issue, 1921-1933. New York: Fordham University Press, 1993.

Hinloopen, Jeroen. "Cartel Stability with Time-Dependent Detection Probabilities." Working Paper, University of Amsterdam and ENCORE, November 2003.

Irons, Peter H. The New Deal Lawyers. Princeton: Princeton University Press, 1982.

Johnson, Hugh S. The Blue Eagle, from Egg to Earth. Garden City, NY: Doubleday, Doran \& Co., 1935.

Kinghorn, Janice R. "Kartells and Cartel Theory: Evidence from Early Twentieth Century German Coal, Iron and Steel Industries." Essays in Economic and Business History 14 (1996): 339-63.

Krepps, Matthew B. "Another Look at the Impact of the National Industrial Recovery Act on Cartel Formation and Maintenance Costs." Review of Economics and Statistics 79, no.1 (1997): 151-54.

Leuchtenburg, William E. and the Editors of LIFE. The LIFE History of the United States Volume 11: New Deal and Global War. New York: Time Inc., 1964.

Levenstein, Margaret C. "Price Wars and the Stability of Collusion: A Study of the PreWorld War I Bromine Industry." Journal of Industrial Economics 45, no. 2 (1997): $117-37$.

Levenstein, Margaret C. and Valerie Y. Suslow. "Studies of Cartel Stability: A Comparison of Methodological Approaches." In Peter Z. Grossman, ed., How Cartels Endure and How They Fail: Studies of Industrial Collusion. Northhampton, Mass.: Edward Elgar, 2004, pp. 9-52.

Levenstein, Margaret C. and Suslow, Valerie Y. "What Determines Cartel Success?" Journal of Economic Literature 44, No 1, (2006): 43-95.

Magee, James D., Willard E. Atkins, and Emanual Stein. The National Recovery Program. Binghamton, N.Y.: Vail-Ballou Press, 1933.

Marquez, Jaime. "Life Expectancy of International Cartels: An Empirical Analysis." Review of Industrial Organization 9, No. 3 (1994): 331-341. 
Marshall, Leon C. Hours and Wages Provisions in NRA Codes. Washington, D.C.: Brookings Institution, 1935.

Mason, David Townsend. The Lumber Code. Yale University, School of Forestry, 1935.

O’Brien, Anthony Patrick. "A Behavioral Explanation for Nominal Wage Rigidity During the Great Depression." Quarterly Journal of Economics 104, no. 4 (1989): 719-35.

Pirrong, Stephen C. "An Application of Core Theory to the Study of Ocean Shipping Markets." Journal of Law and Economics 35 (1992): 89-131.

Rotemberg, Julio J. and Saloner, Garth. "A Supergame-Theoretic Model of Price Wars During Booms." American Economic Review 76 (1986): 390-407.

Rothbard, Murray. "The Federal Reserve as a Cartelization Device: The Early Years, 1913-1930." In Barry Siegel, ed., Money in Crisis. San Francisco: Pacific Institute for Public Policy Research, and Cambridge, Mass: Ballinger Publishing Company, 1984, pp. 89-136.

Rothschild, Robert. "Cartel Stability When Costs are Heterogeneous." International Journal of Industrial Organization 17 (1999): 717-34.

Schmalensee, Richard. "Competitive Advantage and Collusive Optima." International Journal of Industrial Organization 5 (1987): 351-67.

Sjostrom, William. "Collusion in Ocean Shipping: A Test of Monopoly and Empty Core Models." Journal of Political Economy 97 (1989): 1160-79.

Stigler, George J. "A Theory of Oligopoly." Journal of Political Economy 72 (1964): 44-61.

Suslow, Valerie. "Cartel Contract Duration: Empirical Evidence from Inter-War International Cartels." Industrial and Corporate Change 15, No. 5 (2005): 705-744.

Taylor, Jason and Selgin, George. "By Our Bootstraps: Origins and Effects of the HighWage Doctrine and the Minimum Wage." Journal of Labor Research 20 (1999): 44762 .

Taylor, Jason E. "The Output Effects of Government Sponsored Cartels During the New Deal." Journal of Industrial Economics 50, no. 1 (2002): 1-10.

Telser, Lester G. "Cooperation, Competition, and Efficiency." Journal of Law and Economics 28 (1985): 271-95.

Telser, Lester G. "Competition and the Core." Journal of Political Economy 104 (1994): 85-107.

Troesken, Werner. "A Note on the Efficacy of German Steel and Coal Syndicates." Explorations in Economic History 18 (1989): 595-600.

U.S. Committee of Industrial Analysis. The National Recovery Administration: Report of the President's Committee of Industrial Analysis. Washington D.C.: Department of Commerce, February 1937. 
U.S. National Recovery Administration. House Document No. 158, 75th Congress, 1st Session. Washington, D.C.: U.S. Government Printing Office, March 2, 1937.

U.S. National Recovery Administration. Basic Codes of Fair Competition. Bulletin No. 2. Washington, D.C.: U.S. Government Printing Office, 1933a.

U.S. National Recovery Administration. Codes of Fair Competition. Volume I. Washington, D.C.: U.S. Government Printing Office, 1933b.

U.S. National Recovery Administration. A Handbook of NRA Laws, Regulations, and Codes. Washington and New York: Federal Codes Inc., 1933c.

U.S. National Recovery Administration. Regulations on Procedures for Local NRA Compliance Boards. Bulletin No. 5. Washington, D.C.: U.S. Government Printing Office, 1933d.

U.S. National Recovery Administration. What the Blue Eagle Means to You and How You Can Get It. Bulletin No. 4. Washington, D.C.: U.S. Government Printing Office, $1933 \mathrm{e}$.

U.S. National Recovery Administration. What is the NRA? A Guide for Study and Discussion. Washington, D.C.: U.S. Government Printing Office, 1934.

Vedder, Richard K., and Lowell E. Gallaway. Out of Work: Unemployment and Government in Twentieth-Century America. New York: Holmes and Meier, 1993.

Weinstein, Michael M. Recovery and Redistribution Under the NIRA. Amsterdam: NorthHolland, 1980.

Wolvin, Andrew D. "The 1933 Blue Eagle Campaign: A Study in Persuasion and Coercion." Ph.D. Dissertation, Purdue University, 1968. 

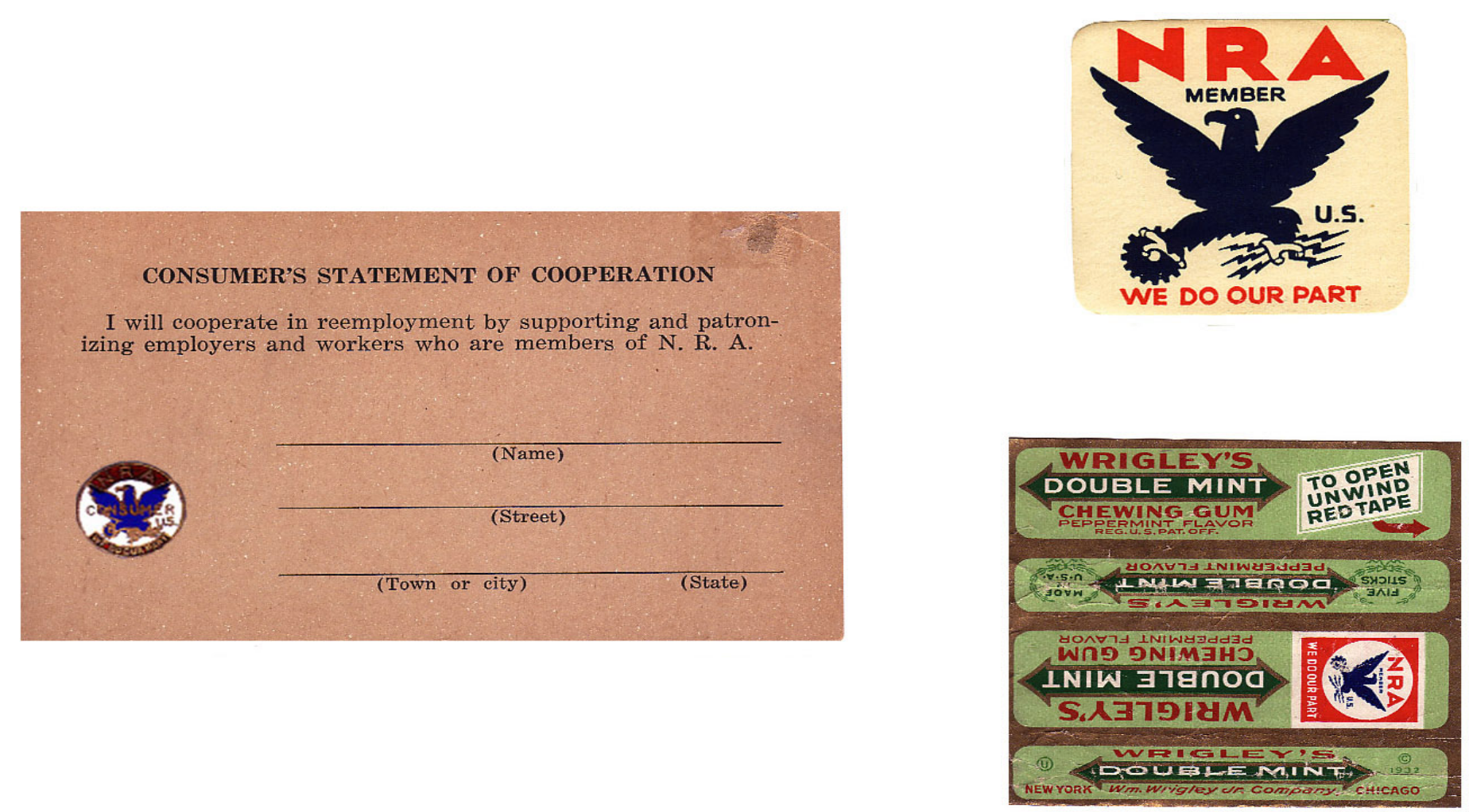

Figure 1

A "Consumer's Statement of Cooperation" card with lapel pin "Badge of Cooperation," a Blue Eagle emblem sticker, and a Wrigley's chewing gum wrapper displaying the Blue Eagle.

Source: Authors' personal collection. 
Figure 2: Appearance of the Blue Eagle

Data are based on a sample of the first 25 advertisements in eight newspapers (200 ads per observation) from every Thursday between August 3, 1933 and June 6, 1935. Newspapers: Atlanta Journal-Constitution, Chicago Tribune, Christian Science Monitor, Lansing State Journal, New Orleans Times-Picayune, New York Times, San Francisco Examiner, and Washington Post.

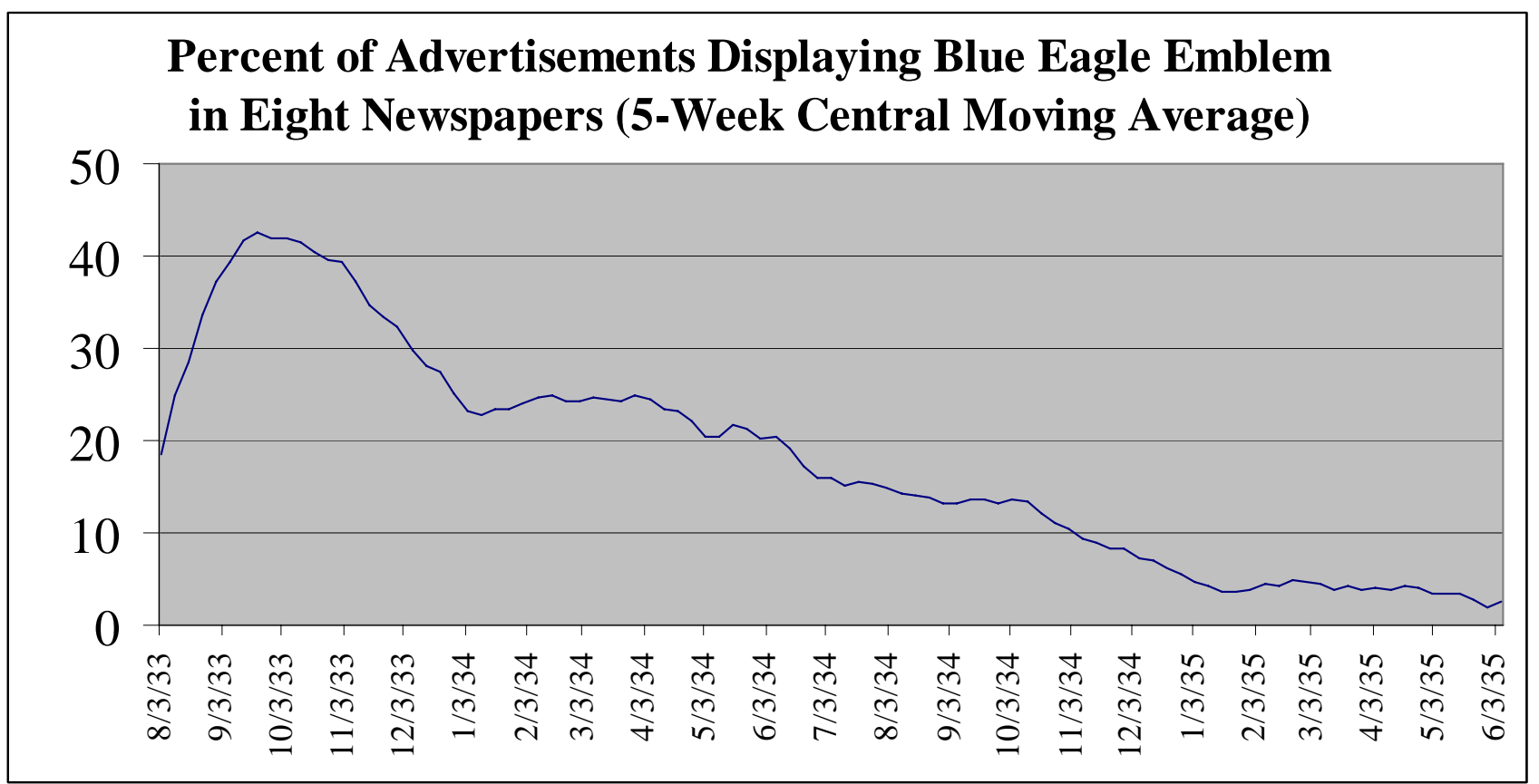


Figure 3: Trade-Practice Provision Complaints

Source: U.S. National Recovery Administration, Research and Planning Division, Charts on the Operation of the National Industrial Recovery Act, Chart 71.

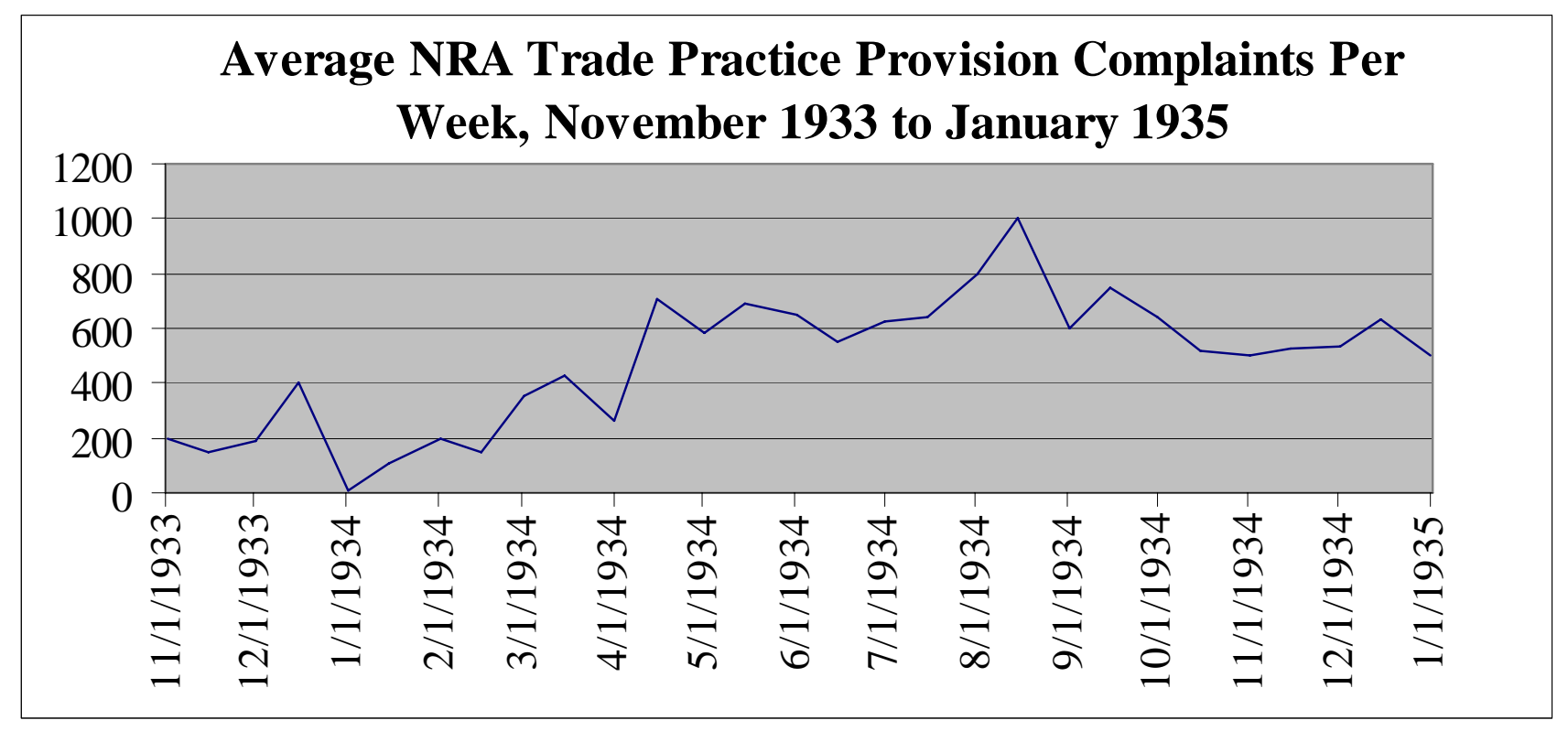


Table 1

\title{
Percent of Advertisements Displaying Blue Eagle Emblem,
} August-December 1933

\author{
Lansing State Journal \\ Chicago Tribune \\ New York Times \\ Washington Post \\ Christian Science Monitor \\ Atlanta Journal-Constitution \\ New Orleans Times-Picayune \\ San Francisco Examiner
}

\begin{tabular}{ccccc}
\multicolumn{5}{c}{ Monthly averages } \\
August & September & October & November & December \\
\hline 0.19 & 0.43 & 0.44 & 0.36 & 0.14 \\
0.50 & 0.65 & 0.57 & 0.60 & 0.56 \\
0.20 & 0.34 & 0.20 & 0.15 & 0.13 \\
0.24 & 0.26 & 0.39 & 0.30 & 0.20 \\
0.17 & 0.19 & 0.30 & 0.22 & 0.21 \\
0.30 & 0.35 & 0.33 & 0.26 & 0.29 \\
0.29 & 0.55 & 0.54 & 0.42 & 0.38 \\
0.41 & 0.65 & 0.52 & 0.47 & 0.36
\end{tabular}


Table 2

Date of Industry Code Passage, Sampled Industries

\begin{tabular}{|c|c|c|c|c|c|}
\hline Industry & $\begin{array}{c}\text { Date Code } \\
\text { Passage }\end{array}$ & $\begin{array}{l}\text { Both Wage + } \\
\text { Output Data }\end{array}$ & Industry & $\begin{array}{c}\text { Date Code } \\
\text { Passage }\end{array}$ & $\begin{array}{l}\text { Both Wage + } \\
\text { Output Data }\end{array}$ \\
\hline Alcohol & 8/21/1934 & & Meat & 1/4/1934 & $*$ \\
\hline American Cheese & 2/2/1935 & & Men's Shoe & 10/3/1933 & $*$ \\
\hline Asphalt & 11/6/1933 & & Merchant Pig Iron & 8/19/1933 & $*$ \\
\hline Auto Parts & 11/8/1933 & & Metal & $11 / 2 / 1933$ & \\
\hline Beef and Veal & $1 / 4 / 1934$ & $*$ & Milk, New York & 1/4/1934 & \\
\hline Bituminous Coal & 9/18/1933 & & Newsprint & 11/17/1933 & $*$ \\
\hline Book & 2/17/1934 & & Paper and Pulp & 11/17/1933 & $*$ \\
\hline Brick & 3/26/1934 & & Paper Production & 11/17/1933 & $*$ \\
\hline Butter & $1 / 4 / 1934$ & & Passenger Cars & 8/26/1933 & $*$ \\
\hline Cement & 11/27/1933 & & Pig Iron & 8/19/1933 & $*$ \\
\hline Cheese & 2/2/1935 & & Pork & $1 / 4 / 1934$ & $*$ \\
\hline Chemicals & 2/10/1934 & $*$ & Raw Silk & 10/7/1933 & \\
\hline Condensed Milk & $1 / 4 / 1934$ & & Rayon & 8/26/1933 & $*$ \\
\hline Construction & 1/31/1934 & & Rayon Yarn & 8/26/1933 & $*$ \\
\hline Copper & 4/21/1934 & & Refined Lead & $5 / 24 / 1934$ & \\
\hline Corn Grindings & $1 / 4 / 1934$ & & Rice & 1/4/1934 & \\
\hline Cotton & 7/9/1933 & $*$ & Rubber & 12/15/1933 & $*$ \\
\hline Cotton Goods & 11/17/1933 & & S $+\mathrm{C}$ Tires & 12/21/1933 & $*$ \\
\hline Crude Petro, Appl. & 8/19/1933 & & Slab Zinc & 3/26/1935 & \\
\hline Crude Petro, RTS & 8/19/1933 & & Small Cigarettes & 2/9/1935 & \\
\hline Douglas Fir Lumber & 8/19/1933 & $*$ & S. Pine Lumber & 8/19/1933 & \\
\hline Evaporated Milk & $1 / 4 / 1934$ & & Steel Ingot & 8/19/1933 & $*$ \\
\hline Fertilizers & 10/31/1933 & & Steel Sheet & 8/19/1933 & $*$ \\
\hline Fine Paper & 11/17/1933 & $*$ & Tire Pneumatic Case & $12 / 21 / 1933$ & $*$ \\
\hline Glass & 10/3/1933 & & Tire Tubes & 12/21/1933 & $*$ \\
\hline Ice Cream & 1/4/1934 & & Total Shoe & 10/3/1933 & $*$ \\
\hline Large Cigars & 6/19/1934 & & Trucks & 8/26/1933 & $*$ \\
\hline Lead Ore & $5 / 24 / 1934$ & & Wheat Flour & $1 / 4 / 1934$ & \\
\hline Leather & 9/7/1933 & $*$ & Women's Shoes & 10/3/1933 & $*$ \\
\hline Locomotives & 2/16/1934 & & Woodworking Mach. & $5 / 14 / 1934$ & $*$ \\
\hline Lubricants & 8/19/1933 & & Wool & 7/26/1933 & $*$ \\
\hline Lumber & 8/19/1933 & & Wrapping Paper & 11/17/1933 & $*$ \\
\hline Machinery & 3/17/1934 & $*$ & Zinc Ore & 3/26/1935 & \\
\hline
\end{tabular}

Notes: We employ output data for all 66 industries above. For the 30 industries with an asterisk, we also have average hourly earnings data. 


\section{Table 3 \\ Impact of the Blue Eagle Emblem on Output and Wage Rates}

Dependent variables as defined in the text. Monthly observations from January 1927 to December 1937. T-statistics in parentheses. ** and * denote statistical significance at the 1 and 5 percent levels, respectively. All regressions employ industry fixed effects and cross-section weights. Standard errors calculated under a Period SUR covariance method.

\section{Dependent Variables}

Log Difference Industry Output

(1)

\begin{tabular}{|c|c|c|c|c|}
\hline Constant & $\begin{array}{c}0.07142 * * \\
(11.02)\end{array}$ & $\begin{array}{c}0.07155^{* *} \\
(11.10)\end{array}$ & $\begin{array}{l}-0.00623^{* *} \\
(-4.87)\end{array}$ & $\begin{array}{l}-0.00647^{* *} \\
(-5.07)\end{array}$ \\
\hline $\begin{array}{l}\text { Pre-Code NIRA Months } \\
\text { (July 1933-Code Passage) }\end{array}$ & $\begin{array}{l}-0.01182^{*} \\
(-2.42)\end{array}$ & $\begin{array}{l}0.01949 * * \\
(2.61)\end{array}$ & $\begin{array}{l}0.02713^{* *} \\
(6.69)\end{array}$ & $\begin{array}{l}0.01879 * * \\
(4.10)\end{array}$ \\
\hline $\begin{array}{l}\text { NIRA Code Months } \\
\text { (Industry Code Passage } \\
\text { through May 1935) }\end{array}$ & $\begin{array}{c}-0.00641^{* *} \\
(-3.16)\end{array}$ & $\begin{array}{l}0.01373^{* *} \\
(3.26)\end{array}$ & $\begin{array}{c}0.00104 \\
(1.18)\end{array}$ & $\begin{array}{l}-0.00416 * * \\
(-3.48)\end{array}$ \\
\hline DLog Money Supply & $\begin{array}{l}-0.11432 * \\
(-2.09)\end{array}$ & $\begin{array}{c}-0.10717 \\
(-1.92)\end{array}$ & $\begin{array}{l}0.12310^{* *} \\
(5.97)\end{array}$ & $\begin{array}{l}0.12058^{* *} \\
(5.86)\end{array}$ \\
\hline DLog Government Spend & $\begin{array}{l}0.00715^{* *} \\
(2.30)\end{array}$ & $\begin{array}{l}0.00870^{* *} \\
(2.77)\end{array}$ & $\begin{array}{l}0.00320^{* *} \\
(5.97)\end{array}$ & $\begin{array}{l}0.00288^{* *} \\
(5.89)\end{array}$ \\
\hline DLog Government Revenue & $\begin{array}{l}0.00073 \\
(0.45)\end{array}$ & $\begin{array}{c}0.00046 \\
(0.29)\end{array}$ & $\begin{array}{c}-0.00041 \\
(-1.53)\end{array}$ & $\begin{array}{r}-0.00040 \\
(-1.47)\end{array}$ \\
\hline Time Trend & $\begin{array}{l}0.00006^{*} \\
(2.14)\end{array}$ & $\begin{array}{c}0.00006 \\
(1.96)\end{array}$ & $\begin{array}{l}0.00002^{* *} \\
(2.92)\end{array}$ & $\begin{array}{l}0.00002^{* *} \\
(3.18)\end{array}$ \\
\hline $\begin{array}{l}\text { Industry Capacity } \\
\text { Utilization }(-1)\end{array}$ & $\begin{array}{l}-0.11638 \\
(-11.98)^{* *}\end{array}$ & $\begin{array}{l}-0.11603^{* *} \\
(-12.03)\end{array}$ & $\begin{array}{l}0.00888^{* *} \\
(5.42)\end{array}$ & $\begin{array}{l}0.00904^{* *} \\
(5.53)\end{array}$ \\
\hline $\begin{array}{l}\text { Percent of Advertisements } \\
\text { with Blue Eagle Emblem }\end{array}$ & & $\begin{array}{l}-0.00130^{* *} \\
(-5.50)\end{array}$ & & $\begin{array}{l}0.00034^{* *} \\
(4.86)\end{array}$ \\
\hline Cross-Sections & 66 & 66 & 30 & 30 \\
\hline Observations & 8372 & 8372 & 3823 & 3823 \\
\hline Durbin-Watson Statistic & 1.88 & 1.88 & 1.81 & 1.82 \\
\hline
\end{tabular}

Log Difference Industry Real Average Hourly Earnings

(4)
(2)
(3) 